\title{
Mixing state of black carbon and its impact on optical properties and radiative forcing over East Asia
}

\author{
Xiaoyan $\mathrm{Ma}^{1}$, Hailing $\mathrm{Jia}^{1}$, Rong Tian ${ }^{1}$, Fangqun $\mathrm{Yu}^{2}$, and Jiangnan $\mathrm{Li}^{3}$ \\ ${ }^{1}$ Collaborative Innovation Center on Forecast and Evaluation of Meteorological Disasters (CIC-FEMD)/Key Laboratory for \\ ${ }^{3}$ Environment and Climate Change Canada, Victoria, BC, Canada
}

Correspondence to: Xiaoyan Ma (xma@nuist.edu.cn)

\begin{abstract}
BC mixing state, one of essential aerosol microphysical properties modulating its optical properties and radiative forcing, and climatic and environmental effect, has often been assumed in numerical models previously. In this study, by employing a nested version of GEOS-Chem-APM model with predicted BC mixing state, we carefully examined the effect of $\mathrm{BC}$ mixing state on aerosol optical properties, radiative forcing, and heating rate over East Asia (EA) and particularly in East-Central China (ECC). The modelling results show that the mass of both BC core and coating by secondary species (coated SS) are significantly high in ECC and India due to strong anthropogenic emissions but quite low in the other regions. The ratio of total mass $(\mathrm{BC}+$ coated $\mathrm{SS})$ to the $\mathrm{BC}$ over ECC can be doubled compared to pure $\mathrm{BC}$ core mass, indicating quite large coating over the regions with high anthropogenic emissions. Absorptive aerosol optical depth (AAOD) enhances 40\% over ECC once core-shell mixing, rather than external mixing, is taken into account, despite AOD only changes slightly, and the resulting absorption amplification (Aa) normally varies from 1.1 to 1.8 over ECC. Aerosol direct radiative

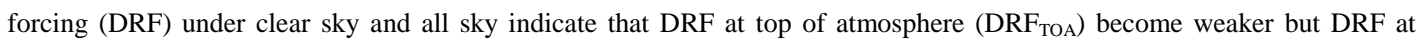
surface $\left(\mathrm{DRF}_{\mathrm{SRF}}\right)$ become stronger when core-shell mixing, instead of external mixing, is taken in to account in the simulation. The simulation with core-shell mixing presented that over ECC, the regional-averaged atmospheric absorption enhances $39 \%$ while $\mathrm{DRF}_{\mathrm{TOA}}$ and $\mathrm{DRF}_{\mathrm{SRF}}$ are reported as -8.3 and $-17.8 \mathrm{~W} \mathrm{~m}^{-2}$, compared to -9.4 and $-16.2 \mathrm{~W}^{-2}$ in the simulation with external mixing state. The heating rate in entire column enhances with core-shell mixing state due to absorption amplification, compared to external mixing state. The heating rate at surface over ECC increases about $43 \%$, i.e. increase from $0.7 \mathrm{~K} \mathrm{day}^{-1}$ (external) to $0.9 \mathrm{~K} \mathrm{day}^{-1}$ (core-shell) during the study period. The results in three cities (Beijing, Nanjing, Chengdu), representative of North China Plain (NCP), Yangtze River Delta (YRD), and Sichuan Basin (SCB), major anthropogenic aerosol emissions regions over EA, are also discussed in the study.
\end{abstract}




\section{Introduction}

Black carbon (BC) particles, which emitted from both anthropogenic (incomplete fossil fuel combustion) and natural sources

(biomass burning), are one of major aerosol components in atmosphere and have significant impacts on climate change and air pollution through modifying solar radiation flux in Earth-atmosphere system (Hansen et al., 2000; Chameides and Bergin, 2002; Menon et al., 2002; Bond and Bergstrom, 2006; Ramanathan and Carmichael, 2008; Gustafsson and Ramanathan, 2016). It is well known that direct radiative forcing (DRF) of aerosol strongly depends on its microphysical properties, including chemical component, size distribution, morphology, and mixing state. BC particles are normally irregularly shaped and mostly solid once emitted, and then externally or internally mixed with other aerosol types by aging process (Bond et al., 2006; Koch et al., 2009; Peng et al., 2016; Liu et al., 2017). The coating of BC particles with secondary aerosol constituents (such as sulfate, nitrate, ammonia, and organics) through aging process can enhance the mass absorption cross-section due to the lensing effect, i.e. the coating materials act as a lens to focus more photons on BC particles (Fuller et al., 1999; Jacobson, 2000; 2001; Lesins et al., 2002; Bond and Bergstrom, 2006; Cheng et al., 2006; Ramanathan and Carmichael, 2008; Lack and Cappa, 2010). This is so-called light amplification (Bond and Bergstrom, 2006). The change of light absorption in the atmosphere will modify radiation flux in the earth-atmosphere system, heating rate, as well as the atmospheric stability (Jacobson,2000; Ding et al.,2016; Wilcox et al., 2016; Gao et al., 2018; Wang et al.,2018).

Light absorption of $\mathrm{BC}$ particles is quite complex since it changes with the morphology and mixing state of the BC-containing particles (Schnaiter et al., 2005; Zhang et al., 2008; Knox et al., 2009; Peng et al., 2016; Bai et al., 2018; Liu et al., 2018), i.e. the degree of internal mixing between BC and other particle species (i.e., non-BC components) is strongly dependent on the atmospheric aging process, such as condensation, coagulation and heterogeneous oxidation. Previous theoretical (Jacobson, 2001; Moffet and Prather, 2009; Zhang et al., 2016) and observational (Knox et al., 2009; Cappa et al., 2012; Chung et al., 2012; Dong et al., 2015; Peng et al., 2016) studies showed a rather broad range of absorption enhancements (1.05-3.05) of BC-containing particles during the atmospheric aging process. In terms of individual BC containing particles, more coating materials result in stronger light absorption capability. The variation of BC optical properties will probably exert significant influence on its radiative forcing based on previous studies, e.g. the studies by Jacobson's $(2000,2001)$ found that $\mathrm{BC}$ forcing with the core-shell treatment is $50 \%$ higher than forcing obtained with the externally-mixed treatment.

During the past few decades, aerosol concentrations (including BC) over China have increased dramatically due to a significant enhancement of anthropogenic emissions with rapid economic development, and have consequently led to serious environmental and climatic problems (Gu et al., 2010; Zhuang et al.,2010; Wang et al., 2012; Zhuang et al., 2014; Ding et al., 2016; Ma and Jia, 2016; Ma et al., 2018; Zhang et al.,2018). For example, the weekly average mass concentration of BC was reported as $4.3 \mu \mathrm{g} \mathrm{m}^{-3}$ according to nine years' measurements during 2005 to 2013 in Beijing (Chen et al., 2016). Other measurements in the summer of 2005 gave the average mass concentration of BC as $2.37( \pm 1.79)$ and $5.47( \pm 4.00) \mu \mathrm{g} \mathrm{m}^{-3}$ in 
Beijing and Shanghai (Zhou et al., 2009). The measurements at Mt. Tai and nearby urban area in North China indicated that non-BC coatings could enhance the mass absorption cross-section (MAC) of BC particles by a factor of 2, i.e. light absorption of BC is doubled (Bai et al., 2018). Such profoundly enhanced BC absorption induced by high BC loadings and increased coating can significantly modify radiation heating of the atmosphere and thus exhibit climatic and environmental effect. The study by Ding et al. (2016) showed that BC induces heating in the planetary boundary layer (PBL), particularly in the upper PBL, and the resulting decreased surface heat flux substantially depresses the development of PBL and consequently enhances the occurrences of extreme haze pollution episodes.

As our previous studies (Yu et al., 2012; Ma et al. 2012) presented, the GEOS-Chem-APM model can predict the mixing state of BC particles, i.e. core-shell mixing state, rather than assuming either external mixing or internal mixing, as most previous studies have done. Thus, the predicted mixing state of aerosol particles is physically more realistic than the assumption. In this study, a nested version of GEOS-Chem-APM model is employed to investigate the mixing state of BC on aerosol optical properties, radiative forcing, and heating rate over East Asia. The paper is organized as follows: the descriptions of model and emissions (both anthropogenic and natural) are presented in Section 2 and 3, the simulated mass concentrations of $\mathrm{BC}$ and coating and comparisons with the measurements, while aerosol optical depth and absorption amplification, radiative forcing, and heating rate are presented in Section 4. A summary and discussion is summarized in Section 5.

\section{Model description and experiments design}

\subsection{Nested GEOS-Chem-APM}

The GEOS-Chem is a global chemistry model driven by assimilated meteorological observations from the Goddard Earth Observing System (GEOS) of the NASA Global Modeling Assimilation Office (GMAO), including a number of state-of-the-art modules representing various chemical and aerosol processes (e.g. Bey et al., 2001; Martin et al., 2003; Park et al., 2004; Evans and Jacob, 2005; Liao et al., 2007; Fountoukis and Nenes, 2007) with up-to-date key emission inventories (e.g. Guenther et al., 2006; Bond et al., 2007). The APM (Advanced Particle Microphysics) model (Yu and Luo, 2009), which has been incorporated into GEOS-Chem, is an advanced multi-type, multicomponent, size-resolved microphysics model, in which comprehensive microphysical processes have been parameterized, including nucleation, condensation/evaporation, coagulation, thermodynamic equilibrium with local humidity, and dry and wet deposition. New particle formation is parameterized with the ion-mediated nucleation mechanism (Yu, 2010). As a bin-based aerosol module (e.g. APM) is very computational expensive, a number of algorithms have been employed to improve the computing efficiency (Yu and Luo, 2009). Prognostic aerosol compositions include secondary particles (SP, containing sulfate, ammonia, nitrate and SOAs), BC, primary organic carbon (POC), sea salt and mineral dust. The contributions of nitrate, ammonium, and SOAs to secondary particle growth are considered. The model has been validated extensively with a large number of relevant surface 
measurements and satellite retrievals (Yu and Luo, 2009; Yu et al., 2010; Yu, 2011; Ma et al., 2012; Ma and Yu, 2014; 2015). microphysical properties of aerosol have also been examined in our previous study (Ma et al., 2012). The GEOS-Chem-APM model has been designed to explicitly predict the coating of secondary species on primary particles (sea salt, BC, POC, and dust) and spatiotemporal variations in the degree of particle mixing, thus it is possible for us to explore the impact of mixing state (external and core-shell mixing) on optical properties of BC, radiative forcing, and heating rate.

The nested-grid GEOS-Chem (version 9-01-01) with a spatial resolution of $0.5^{\circ} \times 0.667^{\circ}$ (Chen et al., 2009) is used in this study, with chemical boundary conditions provided by the GEOS-Chem global simulation at a resolution of $4^{\circ} \times 5^{\circ}$. The nested-grid domain is $70^{\circ} \mathrm{E}-150^{\circ} \mathrm{E}, 11^{\circ} \mathrm{S}-55^{\circ} \mathrm{N}$. The nested-grid GEOS-Chem CTM has been evaluated and applied to the analysis of SNA (Sulfate-nitrate-ammonium) and black carbon over China (Wang et al., 2013; Kharol et al., 2013).

To examine the effect of mixing state on optical properties and DRF due to anthropogenic aerosols, two experiments are conducted, i.e. COAT and NoCOAT, with COAT as a base experiment in which core-shell (coating) mixing state is applied, while the experiment NoCOAT is based on the base experiment except assuming aerosol particles as external mixed, i.e. no coating is taken into accounted. Both simulations are conducted for January 2014 over East Asia.

\section{Anthropogenic and natural emissions}

Carbonaceous aerosol emissions include fossil fuel and bio-fuel combustion and biomass burning. In this study, anthropogenic carbonaceous emissions used Bond et al. (2004)'s fossil fuel and bio-fuel inventories, while biomass burning emission is based on Global Fire Emissions Database Version4 (GFED4) monthly open fire inventory (van der Werf et al., 2006). The MIX v1.1 is used to replace the Asian emission inventory (Li et al., 2017). The monthly anthropogenic emissions of $\mathrm{NO}_{\mathrm{x}}, \mathrm{SO}_{2}$, and $\mathrm{NH}_{3}$ over China are taken from the MIX emission inventory for the year of 2010 (Li et al., 2017). Carbonaceous aerosol emissions include fossil fuel and bio-fuel combustion and biomass burning. Carbonaceous aerosols in GEOS-Chem-APM are grouped into hydrophilic and hydrophobic species. Conversion of hydrophobic to hydrophilic carbonaceous aerosols takes place with an e-folding time of 1.2 days based on Cooke et al. (1999).

The monthly mean BC emissions from anthropogenic and biomass burning over East China are shown in Fig. 1. It is obvious that anthropogenic emissions are dominant, particularly over East and Central China (ECC) (the domain is shown as a small blue square in Fig.3a). Anthropogenic emission over ECC varies between $10^{-12}$ to $10^{-10} \mathrm{~kg} \mathrm{~m}^{-2} \mathrm{~s}^{-1}$ due to large industrial emissions, while the emissions over other regions are normally less than $10^{-12} \mathrm{~kg} \mathrm{~m}^{-2} \mathrm{~s}^{-1}$. High anthropogenic emissions are also found over India, with the regional-averaged anthropogenic emissions of $1.04 \times 10^{-11} \mathrm{~kg} \mathrm{~m}^{-2} \mathrm{~s}^{-1}$, only next to ECC $\left(2.13 \mathrm{e}^{-11} \mathrm{~kg} \mathrm{~m}^{-2} \mathrm{~s}^{-1}\right)$. In contrast, the emissions from biomass burning are overall lower than $5 \mathrm{e}^{-12} \mathrm{~kg} \mathrm{~m}^{-2} \mathrm{~s}^{-1}$ over most areas. However, biomass burning emissions over Yangtze River Delta (YRD) and Pearl River Delta (PRD) are significantly 

season.

4 Black carbon concentration, and comparisons with observations

\subsection{Black carbon (BC) burden and surface concentration}

Our earlier study (Ma et al., 2012) showed that secondary species (SS) coated on primary particles are generally much lower than those remaining in SP, but a large fraction (up to 50 80\%) (Yu et al., 2012) can become coated on various primary particles in certain regions, e.g. East Asia (EA). The high-resolution simulations with a nested model version over East Asia (Fig. 2a) show that BC burden present a maximum over ECC and India, with the magnitudes of higher than $1 \mathrm{mg} / \mathrm{m}^{2}$, but varies between 0.1 to $1 \mathrm{mg} / \mathrm{m}^{2}$ over most other areas. This is quite consistent with the spatial distributions of anthropogenic emissions of BC. The region-averaged BC burden over Each Asia and ECC summarized in Table 1 indicates that the burden over ECC is nearly 5 -fold high than over EA.

Similarly, BC concentrations at surface also locate mainly over ECC, where the monthly mean BC concentrations varies between 1.0 to $10 \mu \mathrm{g} \mathrm{m}^{-3}$, with the average of $5.0 \mu \mathrm{g} \mathrm{m}^{-3}$, which is nearly 5 time higher compared to EA ( $\left.1.1 \mu \mathrm{g} \mathrm{m} \mathrm{m}^{-3}\right)$ (Fig.2d). High coating concentrations are consistently found over these regions (Fig.2e), with the largest coating in Beijing-Tian-Hebei (BTH), Yangtze River Delta (YRD), Sichuan Basin (SCB), and Central China (CC), corresponding to heavy haze regions in China. The monthly mean mass of SS coating over ECC, $1.45 \mu \mathrm{g} \mathrm{m}^{-3}$, increase by over three-fold relative to the regional mean $\left(0.39 \mu \mathrm{g} \mathrm{m}^{-3}\right)$. The ratio of total mass (BC core + coated SS) to the mass of BC core (Fig.2f), defined as $\mathrm{M}_{\mathrm{R}}$, generally ranges from 1 to 2 over mainland China. It is noted that $M_{R}$ exhibits higher values in southern China (greater than 1.25) than northern China (less than 1.25).

Fig.3a shows our model domain over EA while the small square inside domain represents ECC region. Fig.3b presents the PDF distribution of $\mathrm{M}_{\mathrm{R}}$ for the total column, below $2 \mathrm{~km}$ and below $1 \mathrm{~km}$ over ECC. Over $71 \%, 77 \%$, and $90 \%$ of $\mathrm{M}_{\mathrm{R}}$ varies from 1.0 to 3.0 for both entire column, below $2 \mathrm{~km}$, and below $1 \mathrm{~km}$, respectively. The maximum of $\mathrm{M}_{\mathrm{R}}$ near surface tend to be lower than that in entire column, and the probability of small $\mathrm{M}_{\mathrm{R}}$ increases in the case of below $1 \mathrm{~km}$ than two other cases, implying that the coating on $\mathrm{BC}$ particles by other soluble aerosol enhances with the height. It is probably suggested that $\mathrm{BC}$ particles become coated due to aging process compared to pure BC particles once emitted. According to measurements-based studies (e.g. Peng et al., 2016), BC aging has two distinct stages, i.e. initial transformation from a fractal to spherical morphology and subsequent growth of fully compact particles. The optical properties of $\mathrm{BC}$ change little during the first stage but absorption largely enhances during the second stage. The measured timescales to achieve complete morphology modification and an absorption amplification factor of 2.4 for $\mathrm{BC}$ particles are estimated to be $2.3 \mathrm{~h}$ and $4.6 \mathrm{~h}$ in Beijing. We 
are unable to examine the timescales of BC morphology based on daily mean model output in current study, but it is clearly to see less coating near surface and more coating with height. below.

Time evolution of the simulated AOD from two experiments have been compared with the Aerosol Robotic NETwork (AERONET) retrievals (Holben et al., 1998; 2001) at the observational sites within the study domain. There are only 7 sites after we applied the cloud-screened and quality-assured AERONET Level 2.0 data (Smirnov et al., 2000), and AOD at $550 \mathrm{~nm}$ obtained by spectral interpolation is employed for comparisons. For consistence, the modelled monthly mean AOD in the grid experiments at all sites have little differences (Fig.5) and all agree overall well with AERONET observations in terms of both magnitudes and temporal variations. Data availability of AERONET AAOD measurements, however, is quite limited compared with AOD after the procedure of data filtering and processing as mentioned above (Fig. 6). From the limited 
measurements, it is found that the model generally reproduces the variations of AAOD in Beijing and Chen-Kung-University, emissions over India in emission inventory are too low and have not been updated, while the emissions in China have been updated as described earlier. The values of AAOD in the experiment COAT (take coating into account) are apparently higher than that in the experiment NoCOAT (without considering coating), and also more close to the AERONET measurements. The statistics summarized in Table 2 (AERONET's results not included due to very limited measurements) shows that AAOD in COAT enhanced by roughly $30 \%$ compared to AAOD in NoCOAT.

The ratio of AAOD in COAT to that in NoCOAT is considered as absorption amplification (Aa) (Bond et al, 2006), which is induced by the amount of both BC-core and coated SS. Figure 7 indicates the absorption amplification (Aa) and its dependency on $\mathrm{M}_{\mathrm{R}}$ and $\mathrm{BC}$ core over ECC, in three representative cities in China including Beijing (BJ), Nanjing (NJ), and Chengdu (CD), representative of North China Plain (NCP), Yangtze River Delta (YRD), and Sichuan Basin (SCB), respectively. For the regional-averaged over ECC, the Aa values enhance with the increase of $M_{R}$, with rapid growth initially $\left(\mathrm{M}_{\mathrm{R}}<2.0\right.$, i.e. relatively less coating) and then slow down, especially when $\mathrm{M}_{\mathrm{R}}$ is greater than around 3.0 (more coating). In addition, it is noted that for a fixed $\mathrm{M}_{\mathrm{R}}$, the Aa values tend to be larger for a higher $\mathrm{BC}$ core burden. These findings are consistent with the results from theoretical calculations based on core-shell Mie theory (Ackerman and Toon, 1981; Seinfeld and Pandis, 1998). The comparisons of the Aa values and its dependency on $\mathrm{M}_{\mathrm{R}}$ and $\mathrm{BC}$ burden in $\mathrm{BJ}, \mathrm{NJ}$ and $\mathrm{CD}$ exhibit some quite differences. It is shown that $\mathrm{M}_{R}$ in $\mathrm{BJ}$ varies between 1.0 to 1.8, while $\mathrm{M}_{R}$ in $\mathrm{NJ}$ and $\mathrm{CD}$ ranges from 1.1 to 3.0, i.e. $\mathrm{M}_{R}$ in $\mathrm{BJ}$ is overall significantly lower than in $\mathrm{NJ}$ and $\mathrm{CD}$, indicating less coating in NCP than two other cities. Compared to $N J$ and $C D$, steeper variation of $A a$ versus $M_{R}$ in $B J$ indicate that the dependency of Aa on $M_{R}$ is more dramatic, especially for higher BC core burden.

\subsection{Impact of mixing state on aerosol radiative forcing}

Aerosol direct radiative forcing (DRF) is strongly associated with particle size, component, and mixing state. The mixing state of aerosol and its impact on DRF have been explored by previous studies (Chylek et al., 1995; Lesins et al., 2002), which found that absorption of internally mixed $\mathrm{BC}$ is amplified compared to the externally mixed case. Experiments in aerosol chamber also measured this amplification (Schnaiter et al., 2005). The simulations by Jacobson $(2000,2001)$ found that BC forcing with the core-shell treatment is $50 \%$ higher than forcing obtained with the externally-mixed treatment, and it was suggested that the real forcing by BC probably fell between that from an external mixture and that from a coated core. Our earlier study (Ma et al., 2012) based on global scale indicated that the DRF could be quite different between core-shell mixed and externally-mixed aerosol. Compared with the experiment for externally-mixed state, the simulations with the model-predicted mixing state (core-shell) suggested that global mean absorption increases $0.29 \mathrm{~W} \mathrm{~m}^{-2}$, while the DRF at top of 
East Asia, central Africa, eastern United States and Polar Regions, i.e. source areas and its transport regions.

In this study, the simulations based on a nested GEOS-Chem-APM model version over East Asia are shown in Fig. 8. Over clear sky condition, strong cooling occurs over East China and its adjacent ocean, as well as India, presumably due to strong anthropogenic emissions and transport, while cooling over other regions are quite weak. The monthly mean statistics over the entire model domain (EA) and East Central China (ECC) summarized in Table 1demonstrate that aerosol DRF over ECC is -13.8 and $-24.5 \mathrm{~W} \mathrm{~m}^{-2}$ at TOA and surface (SFC), respectively, which is 2.1 and 2.6 times higher than over the entire domain (-6.8 and $-9.4 \mathrm{~W} \mathrm{~m}^{-2}$ ). Over all sky condition (Fig.9 and Table 1), aerosol DRF decreases compared to clear sky conditions for both TOA and the surface due to dominant cloud effect. The monthly mean DRF at TOA over all sky decrease to $-4.0 \mathrm{~W} \mathrm{~m}^{-2}$ and $-8.3 \mathrm{~W} \mathrm{~m}^{-2}$ at TOA, and -6.4 and $-17.8 \mathrm{~W} \mathrm{~m}^{-2}$ at surface, for the entire domain and ECC, respectively. The absorption in atmosphere by absorbing aerosols (mainly BC) thus contributes to 2.4 and $9.5 \mathrm{~W} \mathrm{~m}^{-2}$ for the entire domain and ECC.

The results mentioned above are based on the simulations in the case of core-shell mixing. Our study (Figure 9 and Table 1) also show that in comparison to the simulation with external mixed aerosol (experiment NoCOAT, middle column), the simulation with core-shell configuration (experiment COAT, left column) exhibits stronger absorption (right column), i.e. 0.7 $\mathrm{W} \mathrm{m}{ }^{-2}$ more over EA and $2.7 \mathrm{~W} \mathrm{~m}^{-2}$ more over EC. This induces a stronger cooling at surface but weaker cooling at TOA, with the differences of $0.4 \mathrm{~W} \mathrm{~m}^{-2}$ for EA and $1.7 \mathrm{~W} \mathrm{~m}^{-2}$ for EC.

\subsection{Heating rate}

The radiative heating rate is equal to divergence of the net solar flux (downward minus upward) for a specific atmospheric layer, thus the heating rate of an atmospheric layer can be computed from the ratio of net heat flux and the thickness of the atmospheric layer (Liou, 2002). The heating rate from the ground to $10 \mathrm{~km}$ are presented in Figure 10 for ECC and three representative cities in China, i.e. Beijing, Nanjing, and Chengdu. The mass concentrations of BC core and the coating by secondary particles (SP), as well as the values of $\mathrm{M}_{\mathrm{R}}$ are also presented for analysis. Additional simulation without aerosol effect is included as well for comparison. It is shown that the heating rating in the simulations without including the radiative effect of aerosols is around $0.4 \mathrm{~K} \mathrm{day}^{-1}$ at surface and decreases with height. The radiative effect of aerosol particles significantly enhances the heating rate below $3 \mathrm{~km}$, which is consistent with the vertical profiles of aerosol mass concentrations. The enhancement of the effect of core-shell configuration on heating rate, compared with the case of external mixing state, is also profound, specifically below $4 \mathrm{~km}$. The regional-averaged heating rate at surface over ECC enhances from $0.7 \mathrm{~K}_{\text {day }}{ }^{-1}$ (external mixing) to $0.9 \mathrm{~K} \mathrm{day}^{-1}$ (core-shell mixing). The degree of enhancement is sensitive to mass concentrations of both $\mathrm{BC}$ core and coated-SP, as well as their ratios $\left(\mathrm{M}_{\mathrm{R}}\right)$. Comparisons of the results in three cities (Fig. 10b, c, d) show that in 
$30 \%$ ), i.e. from 1.0 (aerosol external mixing) to 1.3 (core-shell) $\mathrm{K} \mathrm{day}^{-1}$, which is induced by high mass concentrations of both $\mathrm{BC}$ core and shell. It is also noted that the $\mathrm{M}_{\mathrm{R}}$ is relatively low in Beijing in comparison to other cities, i.e. less coating mass concentration, thus the absorption amplification and the differences in heating rate between external and core-shell mixing are smaller than in Nanjing.

\section{Summary and conclusions}

BC mixing state is a key factor to influence aerosol optical properties, and its direct and indirect effect. As a major industrial region, East Asia is characterized by quite complex aerosol microphysical properties, including chemical component, size distribution, and mixing state. Many previous modelling studies have investigated the impact of mixing state on aerosol optical properties and radiative forcing, but most of them were conducted under the assumption of either external or internal mixing. In this study, we examined the effect of BC mixing state on aerosol optical properties $\mathrm{BC}$, radiative forcing, and heating rate over East Asia (EA) and particularly in East-Central China (ECC), based on a nested version of GEOS-Chem-APM model simulations, in which aerosol mixing state is predicted on line.

Two simulations are conducted during January 2014, with COAT as a base experiment in which core-shell mixing state is applied, while the experiment NoCOAT is same as COAT except external mixed is assumed. It is found that the mass of both BC core and coating by secondary species are quite high over ECC and India, which is clearly induced by strong anthropogenic emissions. The ratio of total mass ( $\mathrm{BC}$ core + coated SS) to the $\mathrm{BC}$ core, defined as $\mathrm{M}_{\mathrm{R}}$ in the study, varies from 1 to 2 over ECC, indicating that total mass could be doubled than pure BC core due to the contribution of coating in some cases. The PDF distribution of $\mathrm{M}_{\mathrm{R}}$ presents that small $\mathrm{M}_{\mathrm{R}}$ occurs more frequently below $1 \mathrm{~km}$ than below $2 \mathrm{~km}$ and entire column, implying that the coating enhances with height due to aging process. Comparisons in two experiments indicate that AAOD over ECC increases over $40 \%$ when core-shell mixing is taken into account although total AOD remain almost identical. Time evolution of AOD and AAOD in AERONET sites within the study domain further confirm that two experiments can both capture the observed variations and magnitudes of AOD, but the modelled AAOD with COAT is obviously higher than NoCOAT and more consistent with AERONET. Absorption amplification (Aa), a function of both BC core mass and $\mathrm{M}_{R}$, increases with $\mathrm{BC}$ mass and $\mathrm{M}_{\mathrm{R}}$ and varies normally between 1.1 to 1.8 over ECC. A comparative analysis in three representative cities over ECC apparently show that $\mathrm{M}_{\mathrm{R}}$ and $\mathrm{BC}$ mass are overall lower in Beijing than in Nanjing and Chengdu, indicating relatively weak coating in Beijing. Aerosol direct radiative forcing (DRF) under clear sky from two experiments are calculated as $-6.8 \mathrm{~W} \mathrm{~m}^{-2}$ (COAT) and $-7.2 \mathrm{~W} \mathrm{~m}^{-2}$ (NoCOAT) at TOA, and $-9.4 \mathrm{~W} \mathrm{~m}^{-2}$ (COAT) and $-9.0 \mathrm{~W} \mathrm{~m}^{-2}$ (NoCOAT) at surface over the entire study domain, i.e. the simulation with core-shell mixing will reduce DRF at TOA but enhance DRF at surface. The reduction at TOA and enhancement at surface will increase to 1.1 and $1.8 \mathrm{~W} \mathrm{~m}^{-2}$ at 
from $6.8 \mathrm{~W} \mathrm{~m}^{-2}$ (external mixing) to $9.5 \mathrm{~W} \mathrm{~m}^{-2}$ (core-shell) over ECC. The heating rate in the entire column increases in the simulation with core-shell mixing than with external mixing due to absorption amplification. The heating rate at surface induced by aerosols is estimated to $0.32 \mathrm{~K} \mathrm{day}^{-1}$, in comparison to the values of $0.4 \mathrm{~K}_{\text {day }}{ }^{-1}$ (without aerosols), which further increases to $0.5 \mathrm{~K} \mathrm{day}^{-1}$, once core-shell mixing is considered. The results at three representative cities in ECC indicate that both the heating rate induced by aerosol and the discrepancies between external or core-shell mixing are relatively small in Beijing, but large in Chengdu.

It is expected the change of radiation flux in atmospheric vertical profile induced by aerosol mixing state will inevitable modulate boundary layer height and consequently enhances the occurrences of haze episodes. In addition, the change of atmospheric vertical profile, as well as the change of aerosol size and hygroscopic properties and thus aerosol-cloud interaction, will probably substantially influence surface temperature and precipitation. Further studies employing a weather or climate model are necessary to address these issues.

Competing interests. The authors declare that they have no conflict of interest.

Acknowledgements. This study is supported by the National Natural Science Foundation of China grants (41975002, 41675004 and 41475005).

\section{References}

Ackerman, T. P. and Toon, O. B.: Absorption of visible radiation in atmosphere containing mixtures of absorbing and non-absorbing particles, Appl. Optics, 20, 3661-3668, https://doi.org/10.1364/AO.20.003661, 1981.

Aouizerats, B., Thouron, O., Tulet, P., Mallet, M., Gomes, L., and Henzing, J. S.: Development of an online radiative module for the computation of aerosol optical properties in 3-D atmospheric models: validation during the EUCAARI campaign, Geosci. Model Dev., 3, 553-564, https://doi.org/10.5194/gmd-3-553-2010, 2010.

Bai, Z., Cui, X., Wang, X., Xie, H., and Chen, B.: Light absorption of black carbon is doubled at Mt. Tai and typical urban area in North China, Sci. Total Environ., 635, 1144-1151, https://doi.org/10.1016/j.scitotenv.2018.04.244, 2018.

Balkanski, Y., Schulz, M., Claquin, T., and Guibert, S.: Reevaluation of mineral aerosol radiative forcings suggests a better agreement with satellite and AERONET data, Atmos. Chem. Phys., 7, 81-95, https://doi.org/10.5194/acp-7-81-2007, 2007.

Bey, I., Jacob, D., Yantosca, R., Logan, J., Field, B., Fiore, A., Li, Q., Liu, H., Mickley, L., and Schulz, M.: Global modeling of tropospheric chemistry with assimilated meteorology: Model description and evaluation, J. Geophys. Res., 106, 23073-23096, https://doi.org/10.1029/2001jd000807, 2001.

Bond, T. C. and Bergstrom, R. W.: Light absorption by carbonaceous particles: An investigative review, Aerosol Sci. Tech., 40, 27-67, https://doi.org/10.1080/02786820500421521, 2006.

Bond, T. C., Bhardwaj, E., Dong, R., Jogani, R., Jung, S., Roden, C., Streets, D. G., and Trautmann, N. M.: Historical emissions of black and organic carbon aerosol from energy-related combustion, 1850-2000, Global Biogeochem. Cy., 21, 
GB2018, https://doi.org/10.1029/2006gb002840, 2007.

Bond, T. C., Habib, G., and Bergstrom, R. W.: Limitations in the enhancement of visible light absorption due to mixing state,

J. Geophys. Res., 111, D20211, https://doi.org/10.1029/2006JD007315, 2006.

Bond, T. C., Streets, D. G., Yarber, K. F., Nelson, S. M., Woo, J.-H., and Klimont, Z.: A technology-based global inventory of black and organic carbon emissions from combustion. J. Geophys. Res., 109, D14203, https://doi.org/10.1029/2003JD003697, 2004.

Cappa, C. D., Onasch, T. B., Massoli, P., Worsnop, D. R., Bates, T. S., Cross, E. S., Davidovits, P., Hakala, J., Hayden, K. L., Jobson, B. T., Kolesar, K. R., Lack, D. A., Lerner, B. M., Li, S.-M., Mellon, D., Nuaaman, I., Olfert, J. S., Petäjä, T., Quinn, P. K., Song, C., Subramanian, R., Williams, E. J., and Zaveri, R. A.: Radiative absorption enhancements due to the mixing state of atmospheric black carbon, Science, 337, 1078-1081, https://doi.org/10.1126/science.1223447, 2012.

Chameides, W. L. and Bergin, M.: Soot takes center stage, Science, 297, 2214-2215, https://doi.org/10.1126/science.1076866, 2002.

Chen, D., Wang, Y., McElroy, M. B., He, K., Yantosca, R. M., and Le Sager, P.: Regional CO pollution and export in China simulated by the high-resolution nested-grid GEOS-Chem model, Atmos. Chem. Phys., 9, 3825-3839, https://doi.org/10.5194/acp-9-3825-2009, 2009.

Chen, Y., Schleicher, N., Fricker, M., Cen, K., Liu, X. L., Kaminski, U., Yu, Y., Wu, X. F., and Norra, S.: Long-term variation of black carbon and PM2.5 in Beijing, China with respect to meteorological conditions and governmental measures, Environ. Pollut., 212, 269-278, https://doi.org/10.1016/j.envpol.2016.01.008, 2016.

Cheng, Y. F., Eichler, H., Wiedensohler, A., Heintzenberg, J., Zhang, Y. H., Hu, M., Herrmann, H., Zeng, L. M., Liu, S., Gnauk, T., Brüggemann, E., and He, L. Y.: Mixing state of elemental carbon and non-light-absorbing aerosol components derived from in situ particle optical properties at Xinken in Pearl River Delta of China, J. Geophys. Res.-Atmos., 111, D20204, https://doi.org/10.1029/2005JD006929, 2006.

Chung, C., Lee, K., and Mueller, D.: Effect of internal mixture on black carbon radiative forcing, Tellus B, 64, 10925, https://doi.org/10.3402/tellusb.v64i0.10925, 2012.

Chylek, P., Videen, G., Ngo, D., Pinnick, R., Ronald, G., and Klett, J. D.: Effect of black carbon on the optical properties and climate forcing of sulfate aerosols, J. Geophys. Res., 100, 16325-16332, https://doi.org/10.1029/95JD01465, 1995.

Cooke, W. F., Liousse, C., Cachier, H., and Feichter, J.: Construction of a $1 \circ \times 1 \circ$ fossil fuel emission data set for carbonaceous aerosol and implementation and radiative impact in the ECHAM4 model, J. Geophys. Res., 104, 22137-22162, https://doi.org/10.1029/1999JD900187, 1999.

Ding, A. J., Huang, X., Nie, W., Sun, J. N., Kerminen, V. M., Petaja, T., Su, H., Cheng, Y. F., Yang, X. Q., Wang, M. H., Chi, X. G., Wang, J. P., Virkkula, A., Guo, W. D., Yuan, J., Wang, S. Y., Zhang, R. J., Wu, Y. F., Song, Y., Zhu, T., Zilitinkevich, S., Kulmala, M., and Fu, C. B.: Enhanced haze pollution by black carbon in megacities in China, Geophys. Res. Lett., 43, https://doi.org/10.1002/2016GL067745, 2016.

Dong, J., Zhao, J. M., and Liu, L. H.: Morphological effects on the radiative properties of soot aerosols in different internally mixing states with sulfate, J. Quant. Spectrosc. Ra., 165, 43-55, https://doi.org/10.1016/j.jqsrt.2015.06.025, 2015.

Evans, M. J. and Jacob, D. J.: Impact of new laboratory studies of N2O5 hydrolysis on global model budgets of tropospheric nitrogen oxides, ozone, and OH, Geophys. Res. Lett., 32, L09813, https://doi.org/10.1029/2005GL022469, 2005.

Fountoukis, C., and A. Nenes, ISORROPIA II: A computationally efficient thermodynamic equilibrium model for 
K+-Ca2+-Mg2+-NH4+-Na+-SO42-NO3--Cl-H2O aerosols, Atmos. Chem. Phys., 7, 4639-4659, https://doi.org/10.5194/acp-7-4639-2007, 2007.

Fuller, K. A., Malm, W. C., and Kreidenweis, S. M.: Effects of Mixing on Extinction By Carbonaceous Particles, J. Geophys. Res., 014D13, 15941-15954, https://doi.org/10.1029/1998jd100069, 1999.

Gao, J., Zhu, B., Xiao, H., Kang, H., Pan, C., Wang, D., and Wang, H.: Effects of black carbon and boundary layer interaction on surface ozone in Nanjing, China, Atmos. Chem. Phys., 18, 7081-7094, https://doi.org/10.5194/acp-18-7081-2018, 2018.

Gu, Y., Liou, K. N., Chen, W., and Liao, H.: Direct climate effect of black carbon in China and its impact on dust storms, J. Geophys. Res., 115, D00k14, https://doi.org/10.1029/2009jd013427, 2010.

Guenther, A., Karl, T., Harley, P., Wiedinmyer, C., Palmer, P. I., and Geron, C.: Estimates of global terrestrial isoprene emissions using MEGAN (Model of Emissions of Gases and Aerosols from Nature), Atmos. Chem. Phys., 6, 3181-3210, https://doi.org/10.5194/acp-6-3181-2006, 2006.

Gustafsson, Ö. and Ramanathan, V.: Convergence on climate warming by black carbon aerosols, P. Natl. Acad. Sci. USA, 113, 4243-4245, https://doi.org/10.1073/pnas.1603570113, 2016.

Hansen, J., Sato, M., Ruedy, R., Lacis, A., and Oinas, V.: Global warming in the twenty-first century: an alternative scenario, P. Natl. Acad. Sci. USA, 97, 987-9880, https://doi.org/10.1073/pnas.170278997, 2000.

Holben, B. N., Eck, T. F., Slutsker, I., Tanré, D., Buis, J. P., Setzer, A., Vermote, E., Reagan, J. A., Kaufman, Y. J., Nakajima, T., Lavenu, F., Jankowiak, I., and Smirnov, A.: AERONET - a federated instrument network and data archive for aerosol characterization, Remote Sens. Environ., 66, 1-16, https://doi.org/10.1016/S0034-4257(98)00031-5, 1998.

Holben, B. N., Tanré, D., Smirnov, A., Eck, T. F., Slutsker, I., Abuhassan, N., Newcomb, W. W., Schafer, J. S., Chatenet, B., Lavenu, F., Kaufman, Y. J., Vande Castle, J., Setzer, A., Markham, B., Clark, D., Frouin, R., Halthore, R., Karneli, A., O’Neill, N. T., Pietras, C., Pinker, R. T., Voss, K. and Zibordi, G.: An emerging ground-based aerosol climatology: aerosol optical depth from AERONET, J. Geophys. Res., 106, 12067-12097, https://doi.org/10.1029/2001JD900014, 2001.

Jacobson, M. Z.: A physically-based treatment of elemental carbon optics: Implications for global direct forcing of aerosols, Geophys. Res. Lett., 27, 217-220, https://doi.org/10.1029/1999GL010968, 2000.

Jacobson, M. Z.: Strong radiative heating due to the mixing state of black carbon in atmospheric aerosols, Nature, 409, 695-697, https://doi.org/10.1038/35055518, 2001.

Kharol, S. K., Martin, R. V., Philip, S., Vogel, S., Henze, D. K., Chen, D., Wang, Y., Zhang, Q., and Heald, C. L.: Persistent sensitivity of Asian aerosol to emissions of nitrogen oxides, Geophys. Res. Lett., 40, 1021-1026, https://doi.org/10.1002/grl.50234, 2013.

Knox, A., Evans, G. J., Brook, J. R., Yao, X., Jeong, C. H., Godri, K. J., Sabaliauskas, K., and Slowik, J. G.: Mass absorption cross-section of ambient black carbon aerosol in relation to chemical age, Aerosol Sci. Tech., 43, 522-532, https://doi.org/10.1080/02786820902777207, 2009.

Koch, D., Schulz, M., Kinne, S., McNaughton, C., Spackman, J. R., Balkanski, Y., Bauer, S., Berntsen, T., Bond, T. C., Boucher, O., Chin, M., Clarke, A., De Luca, N., Dentener, F., Diehl, T., Dubovik, O., Easter, R., Fahey, D. W., Feichter, J., Fillmore, D., Freitag, S., Ghan, S., Ginoux, P., Gong, S., Horowitz, L., Iversen, T., Kirkevåg, A., Klimont, Z., Kondo, Y., Krol, M., Liu, X., Miller, R., Montanaro, V., Moteki, N., Myhre, G., Penner, J. E., Perlwitz, J., Pitari, G., Reddy, S., 
Sahu, L., Sakamoto, H., Schuster, G., Schwarz, J. P., Seland, Ø., Stier, P., Takegawa, N., Takemura, T., Textor, C., van Aardenne, J. A., and Zhao, Y.: Evaluation of black carbon estimations in global aerosol models, Atmos. Chem. Phys., 9, 9001-9026, https://doi.org/10.5194/acp-9-9001-2009, 2009.

Krekov, M.: Aerosols Effects on Climate, Univerity of Arizona Press, USA, 9-72, 1993.

Lack, D. A. and Cappa, C. D.: Impact of brown and clear carbon on light absorption enhancement, single scatter albedo and absorption wavelength dependence of black carbon, Atmos. Chem. Phys., 10, 4207-4220, https://doi.org/10.5194/acp-10-4207-2010, 2010.

Lesins, G., P. Chylek, and U. Lohmann: A study of internal and external mixing scenarios and its effect on aerosol optical properties and direct radiative forcing, J. Geophys. Res., 107, 4094, https://doi.org/10.1029/2001JD00973, 2002.

Li, M., Zhang, Q., Kurokawa, J.-I., Woo, J.-H., He, K., Lu, Z., Ohara, T., Song, Y., Streets, D. G., Carmichael, G. R., Cheng, Y., Hong, C., Huo, H., Jiang, X., Kang, S., Liu, F., Su, H., and Zheng, B.: MIX: a mosaic Asian anthropogenic emission inventory under the international collaboration framework of the MICS-Asia and HTAP, Atmos. Chem. Phys., 17, 935-963, https://doi.org/10.5194/acp-17-935-2017, 2017.

Liao, H., Henze, D. K., Seinfeld, J. H., Wu, S., and Mickley, L. J.: Biogenic secondary organic aerosol over the United States: Comparison of climatological simulations with observations, J. Geophys. Res., 112, D06201, https://doi.org/10.1029/2006JD007813, 2007.

Liou, K. N.: An introduction to atmospheric radiation, Elsevier Science, 2002.

Liu, C., C. E. Chung, Y. Yin, and M. Schnaiter: The absorption Ångström exponent of black carbon: from numerical aspects, Atmos. Chem. Phys., 18, 6259-6273, https://doi.org/10.5194/acp-18-6259-2018, 2018.

Liu, D., Whitehead, J., Alfarra, M. R., Reyes-Villegas, E., Spracklen, D. V., Reddington, C. L., Kong, S., Williams, P. I., Ting, Y.-C., Haslett, S., Taylor, J. W., Flynn, M. J., Morgan, W. T., McFiggans, G., Coe, H., and Allan, J. D.: Black-carbon absorption enhancement in the atmosphere determined by particle mixing state, Nat. Geosci., 10, 184-188, https://doi.org/10.1038/ngeo2901, 2017.

Ma, X., Yu, F., and Luo, G.: Aerosol direct radiative forcing based on GEOS-Chem-APM and uncertainties, Atmos. Chem. Phys., 12, 5563-5581, https://doi.org/10.5194/acp-12-5563-2012, 2012.

Ma, X. and Yu, F.: Seasonal variability of aerosol vertical profiles over east US and west Europe: GEOS-Chem/APM simulation and comparison with CALIPSO observations, Atmos. Res., 140-141, 28-37, https://doi.org/10.1016/j.atmosres.2014.01.001, 2014.

Ma, X. and Yu, F.: Seasonal and spatial variations of global aerosol optical depth: multi-year modelling with GEOS-Chem-APM and comparisons with multiple platform observations, Tellus B, 67, 25115, https://doi.org/10.3402/tellusb.v67.25115, 2015.

Ma, X., and Jia, H.: Particulate matter and gaseous pollutions in three megacities over China: situation and implication. Atmos. Environ., 140, 476-494, https://doi.org/10.1016/j.atmosenv.2016.06.008, 2016.

Ma, X. Y., Sha, T., Wang, J. Y., Jia, H. L., and Tian, R.: Investigating impact of emission inventories on PM2.5 simulations over North China Plain by WRF-Chem, Atmos. Environ., 195, 125-140, https://doi.org/10.1016/j. atmosenv.2018.09.058, 2018.

Martin, R. V., Jacob, D. J., Yantosca, R. M., Chin, M., and Ginoux, P.: Global and regional decreases in tropospheric oxidants from photochemical effects of aerosols, J. Geophys. Res., 108, 4097, https://doi.org/10.1029/2002JD002622, 
2003.

Menon, S., Hansen, J., Nazarenko, L., and Luo, Y.: Climate effects of black carbon aerosols in China and India, Science, 297, 2250- 2253, https://doi.org/10.1126/science.1075159, 2002.

Moffet, R. C. and Prather, K. A.: In-situ measurements of the mixing state and optical properties of soot with implications for radiative forcing estimates, P. Natl. Acad. Sci. USA, 106, 11872- 11877, https://doi.org/10.1073/pnas.0900040106, 2009.

Park, R. J., Jacob, D. J., Field, B. D., Yantosca, R. M., and Chin, M.: Natural and transboundary pollution influences on sulfate-nitrate-ammonium aerosols in the United States: Implications for policy, J. Geophys. Res., 109, D15204, https://doi.org/10.1029/2003JD004473, 2004.

Peng, J. F., Hu, M., Guo, S., Du, Z. F., Zheng, J., Shang, D. J., Zamora, M. L., Zeng, L. M., Shao, M., Wu, Y. S., Zheng, J., Wang, Y., Glen, C. R., Collins, D. R., Molina, M. J., and Zhang, R. Y.: Markedly enhanced absorption and direct radiative forcing of black carbon under polluted urban environments, P. Natl. Acad. Sci. USA, 113, 4266-4271, https://doi.org/10.1073/pnas.1602310113, 2016.

Ramanathan, V. and Carmichael, G.: Global and regional climate changes due to black carbon, Nat. Geosci., 1, 221-227, https://doi.org/10.1038/ngeo156, 2008.

Schnaiter, M., Linke, C., Mohler, O., Naumann, K.H., Saathoff, H., Wagner, R., Schurath, U., and Wehner, B.: Absorption amplification of black carbon internally mixed with secondary organic aerosol. J. Geophys. Res., 110, D19204, https://doi.org/10.1029/2005JD006046, 2005.

Seinfeld, J. H. and Pandis, S. N.: Atmospheric Chemistry and Physics, Wiley, Hoboken, New Jersey, 2006.

Smirnov, A., Holben, B. N., Eck, T. F., Dubovik, O., and Slutsker, I.: Cloud screening and quality control algorithms for the AERONET database, Rem. Sens. Environ., 73, 337-349, https://doi.org/10.1016/S0034-4257(00)00109-7, 2000.

van der Werf, G. R., Randerson, J. T., Giglio, L., Collatz, G. J., Kasibhatla, P. S., and Arellano Jr., A. F.: Interannual variability in global biomass burning emissions from 1997 to 2004, Atmos. Chem. Phys., 6, 3423-3441, https://doi.org/10.5194/acp-6-3423-2006, 2006.

van der Werf, G. R., Randerson, J. T., Giglio, L., Collatz, G. J., Mu, M., Kasibhatla, P. S., Morton, D. C., DeFries, R. S., Jin, Y., and van Leeuwen, T. T.: Global fire emissions and the contribution of deforestation, savanna, forest, agricultural, and peat fires (1997-2009), Atmos. Chem. Phys., 10, 11707-11735, https://doi.org/10.5194/acp-10-11707-2010, 2010.

Wang, T., Jiang, F., Deng, J., Shen, Y., Fu, Q., Wang, Q., Fu, Y., Xu, J., and Zhang, D.: Urban air quality and regional haze weather forecast for Yangtze River Delta region, Atmos. Environ., 58, 70-83, https://doi.org/10.1016/j.atmosenv.2012.01.014, 2012.

Wang, Y., Zhang, Q. Q., He, K., Zhang, Q., and Chai, L.: Sulfate-nitrate-ammonium aerosols over China: response to 2000-2015 emission changes of sulfur dioxide, nitrogen oxides, and ammonia, Atmos. Chem. Phys., 13, 2635-2652, https://doi.org/10.5194/acp-13-2635-2013, 2013.

Wang, Z., Huang, X., and Ding, A.: Dome effect of black carbon and its key influencing factors: a one-dimensional modelling study, Atmos. Chem. Phys., 18, 2821-2834, https://doi.org/10.5194/acp-18-2821-2018, 2018.

Wilcox, E. M., Thomas, R. M., Praveen, P. S., Pistone, K., Bender, F. A., and Ramanathan, V.: Black carbon solar absorption suppresses turbulence in the atmospheric boundary layer, P. Natl. Acad. Sci. USA, 113, 11794-11799, https://doi.org/10.1073/pnas. 1525746113, 2016.

Yu, F.: Ion-mediated nucleation in the atmosphere: Key controlling parameters, implications, and look-up table, J. Geophy. 
Yu, F.: A secondary organic aerosol formation model considering successive oxidation aging and kinetic condensation of organic compounds: global scale implications, Atmos. Chem. Phys., 11, 1083-1099, https://doi.org/10.5194/acp-11-1083-2011, 2011.

Yu, F. and Luo, G.: Simulation of particle size distribution with a global aerosol model: contribution of nucleation to aerosol and CCN number concentrations, Atmos. Chem. Phys., 9, 7691-7710, https://doi.org/10.5194/acp-9-7691-2009, 2009.

Yu, F., Luo, G., Bates, T., Anderson, B., Clarke, A., Kapustin, V., Yantosca, R., Wang, Y., and Wu, S.: Spatial distributions of particle number concentrations in the global troposphere: Simulations, observations, and implications for nucleation mechanisms, J. Geophys. Res., 115, D17205, https://doi.org/10.1029/2009JD013473, 2010.

Yu, F., Luo, G., and Ma, X.: Regional and global modeling of aerosol optical properties with a size, composition, and mixing state resolved particle microphysics model, Atmos. Chem. Phys., 12, 5719-5736, https://doi.org/10.5194/acp-12-5719-2012, 2012.

Zhang, R., Khalizov, A. F., Pagels, J., Zhang, D., Xue, H., and McMurry, P. H.: Variability in morphology, hygroscopicity, and optical properties of soot aerosols during atmospheric processing, P. Natl. Acad. Sci., 105, 10291-10296, https://doi.org/10.1073/pnas.0804860105, 2008.

Zhang, Y., Zhang, Q., Cheng, Y., Su, H., Kecorius, S., Wang, Z., Wu, Z., Hu, M., Zhu, T., Wiedensohler, A., and He, K.: Measuring the morphology and density of internally mixed black carbon with SP2 and VTDMA: new insight into the absorption enhancement of black carbon in the atmosphere, Atmos. Meas. Tech., 9, 1833-1843, https://doi.org/10.5194/amt-9-1833-2016, 2016.

Zhang, Y., Zhang, Q., Cheng, Y., Su, H., Li, H., Li, M., Zhang, X., Ding, A., and He, K.: Amplification of light absorption of black carbon associated with air pollution, Atmos. Chem. Phys., 18, 9879-9896, https://doi.org/10.5194/acp-18-9879-2018, 2018.

Zhou, X., Gao, J., Wang, T., Wu, W., and Wang, W.: Measurement of black carbon aerosols near two Chinese megacities and the implications for improving emission inventories, Atmos. Environ., 43, 3918-3924, https://doi.org/10.1016/j.atmosenv.2009.04.062, 2009.

Zhuang, B. L., Liu, L., Shen, F. H., Wang, T. J., and Han, Y.: Semidirect radiative forcing of internal mixed black carbon cloud droplet and its regional climatic effect over China, J. Geophys. Res., 115, D00K19, https://doi.org/10.1029/2009JD013165, 2010.

Zhuang, B. L., Wang, T. J., Li, S., Liu, J., Talbot, R., Mao, H. T., Yang, X. Q., Fu, C. B., Yin, C. Q., Zhu, J. L., Che, H. Z., and Zhang, X. Y.: Optical properties and radiative forcing of urban aerosols in Nanjing, China, Atmos. Environ., 83, 43-52, https://doi.org/10.1016/j.atmosenv.2013.10.052, 2014. 


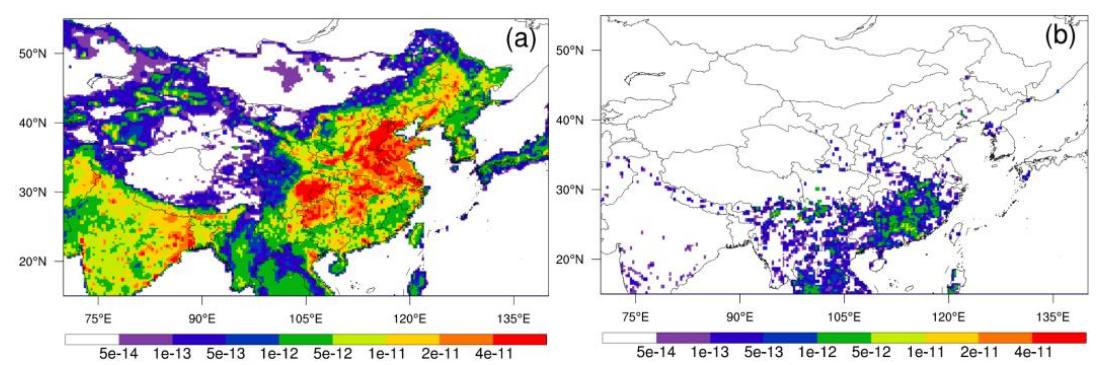

Fig.1. (a) Emissions over East Asia in this study, in which anthropogenic emissions from MIX (a), while biomass burning emissions from GFED4 (b). Units: $\mathrm{kg} \mathrm{m}^{-2} \mathrm{~s}^{-1}$.
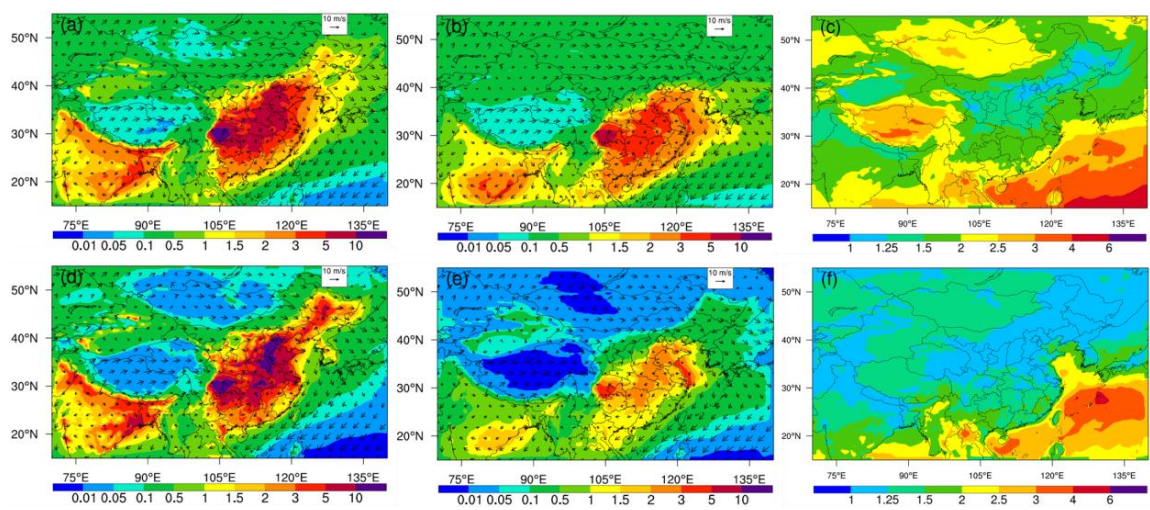

Fig. 2. The top column and bottomn column is for mass burden and surface concentration (the lowest model level). From left to right is the mass of BC core $(\mathrm{a}, \mathrm{d})$, coated SS (b,e), and the ratio of total mass (BC core + coated SS) to the mass of $B C$ core $\left(M_{R}\right)(c, f)$. Wind fields are also shown here for analysis. Units: $\mathrm{mg} \mathrm{m}^{-2}$ for burden and $\mu \mathrm{g} \mathrm{m}^{-3}$ for surface concentration.
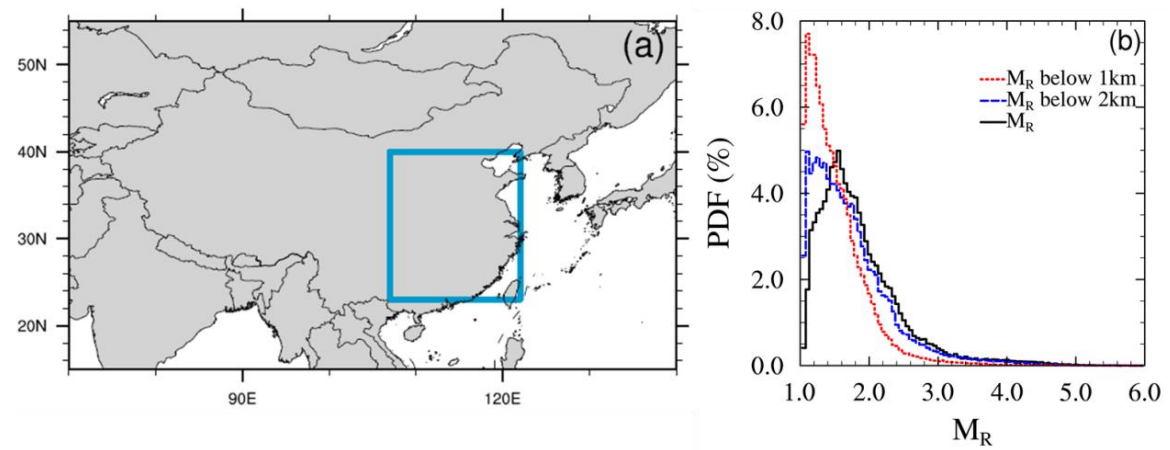

Fig.3. The model domain (a) and probability density function (PDF) distribution of $\mathrm{M}_{\mathrm{R}}$ for the entire column, below $1 \mathrm{~km}$, and below $2 \mathrm{~km}$ over ECC (denoted as small square inside the model domain) (b). 


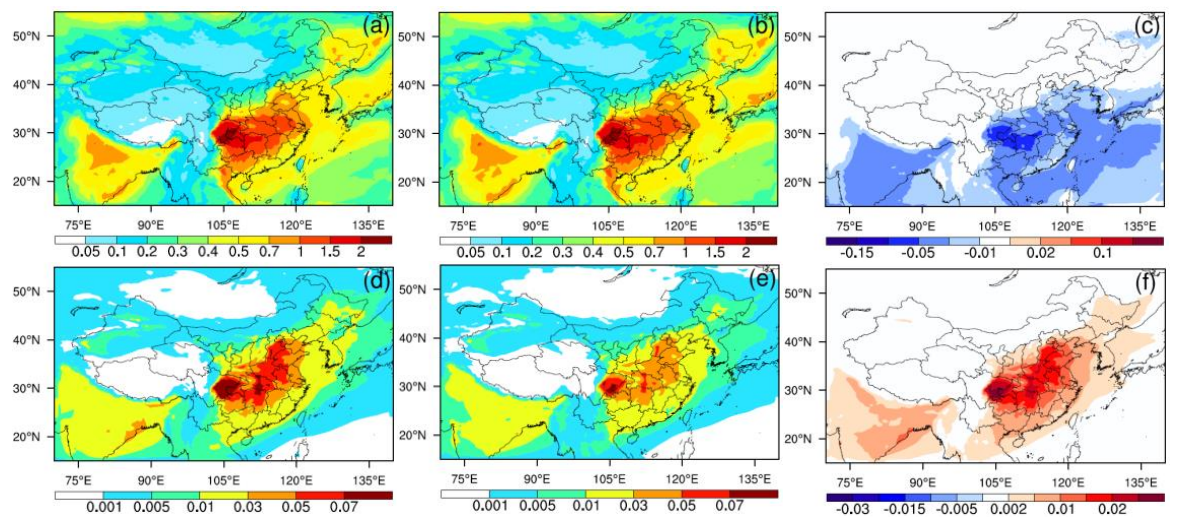

Fig. 4. Simulated AOD (upper), AAOD (lower) from the experiments COAT (left column) and NoCOAT (middle column), and their difference between two experiments (right column).
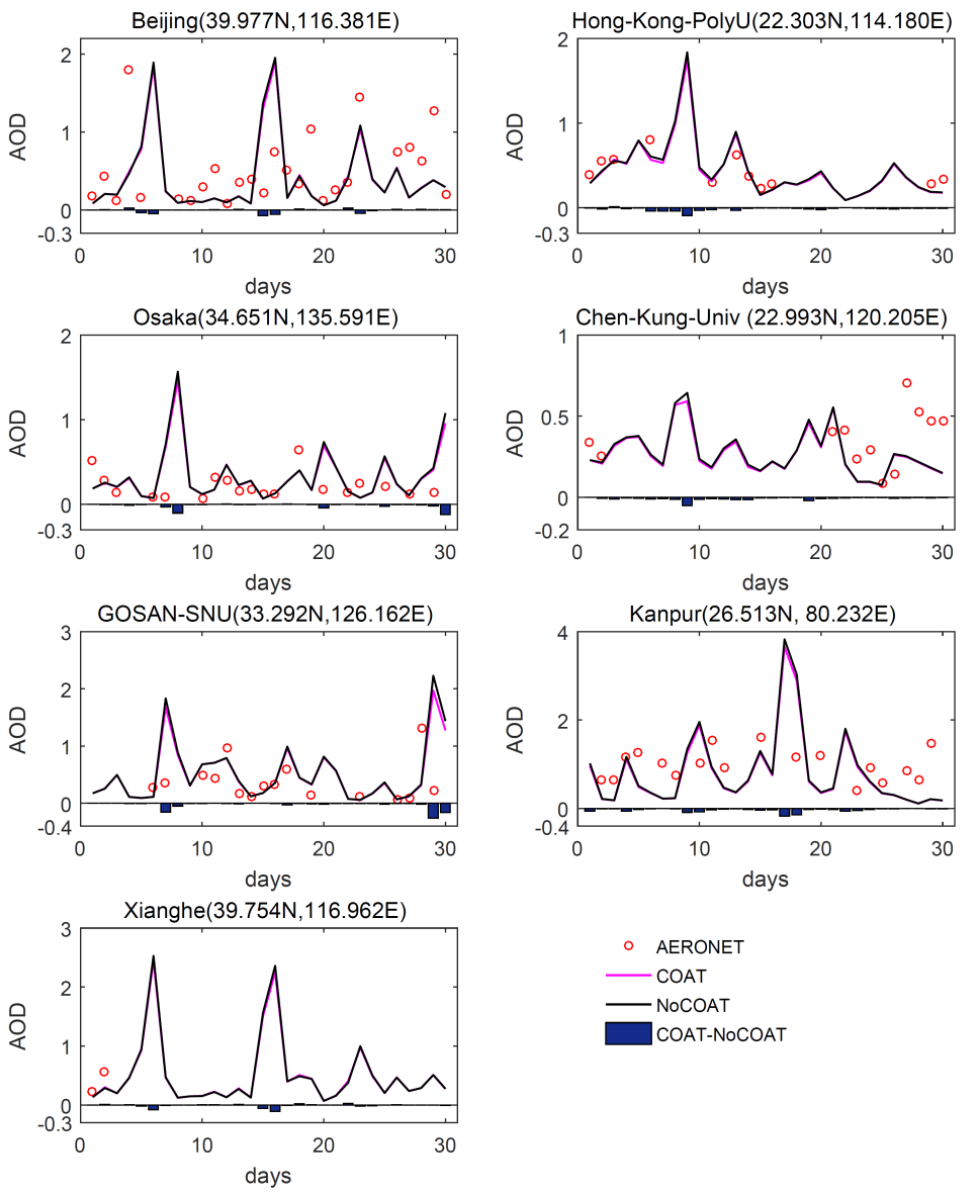

Fig.5. Time series of the modeled AOD from two experiments and their comparisons with AERONET measurements at 7 AERONET sites over East Asia. 

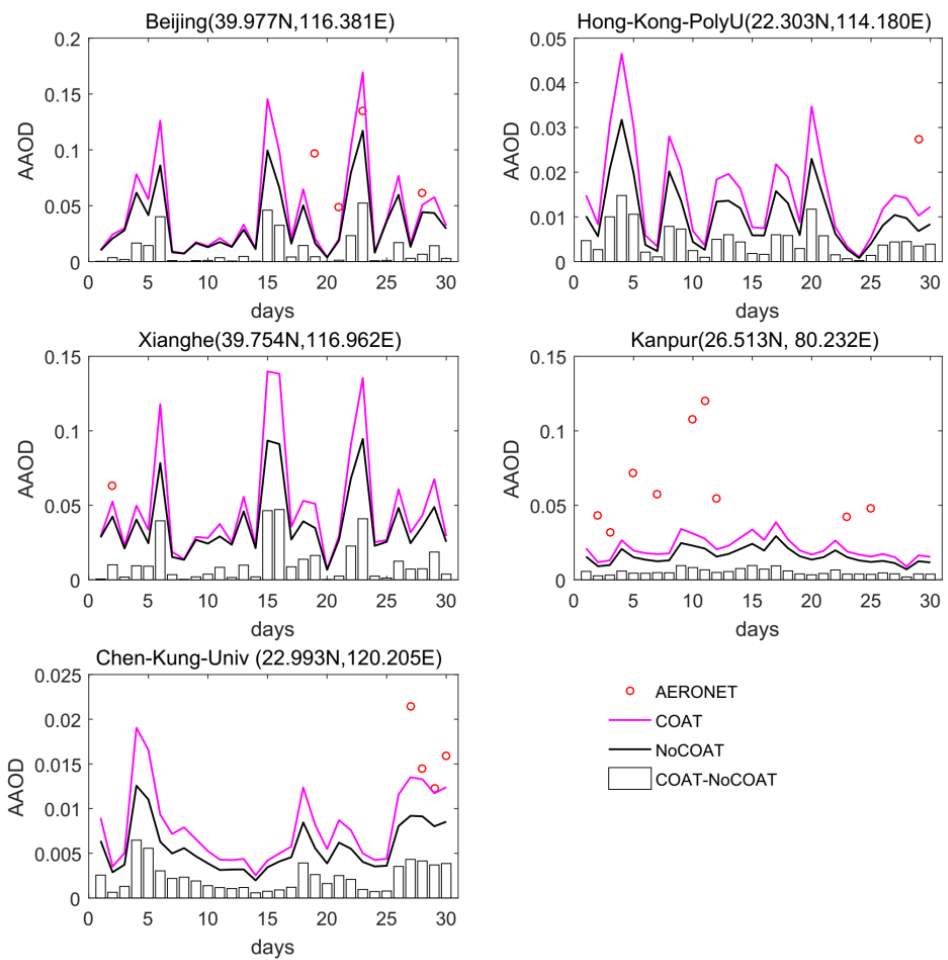

Fig. 6. Time series of the modeled AAOD from two experiments and their comparisons with AERONET measurements at 5 AERONET sites over East Asia.
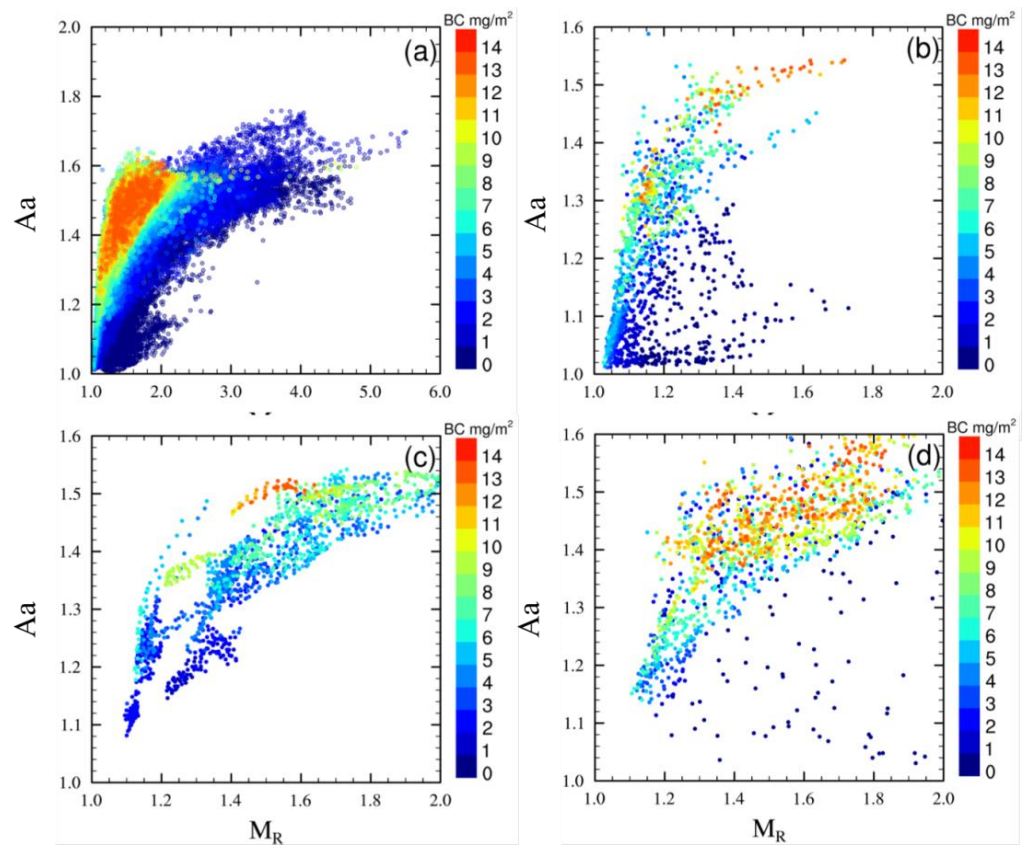

Fig. 7. Absorption amplification (Aa) and its dependency on $M_{R}$ and BC core over EC (a), Beijing (b), Nanjing (c), and Chengdu (d). 


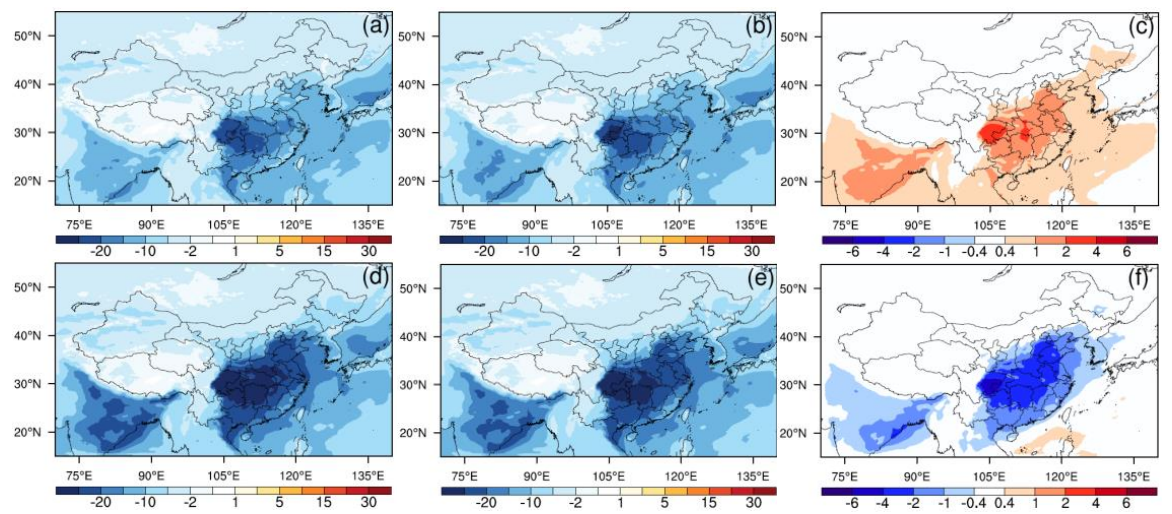

Fig.8. DRF under clear sky at TOA (top column) and SRF (bottom column). The DRFs shown from left to right are the results from $\operatorname{COAT}(\mathrm{a}, \mathrm{d})$, NoCoat $(\mathrm{b}, \mathrm{e})$, and their differences $(\mathrm{c}, \mathrm{f})$.

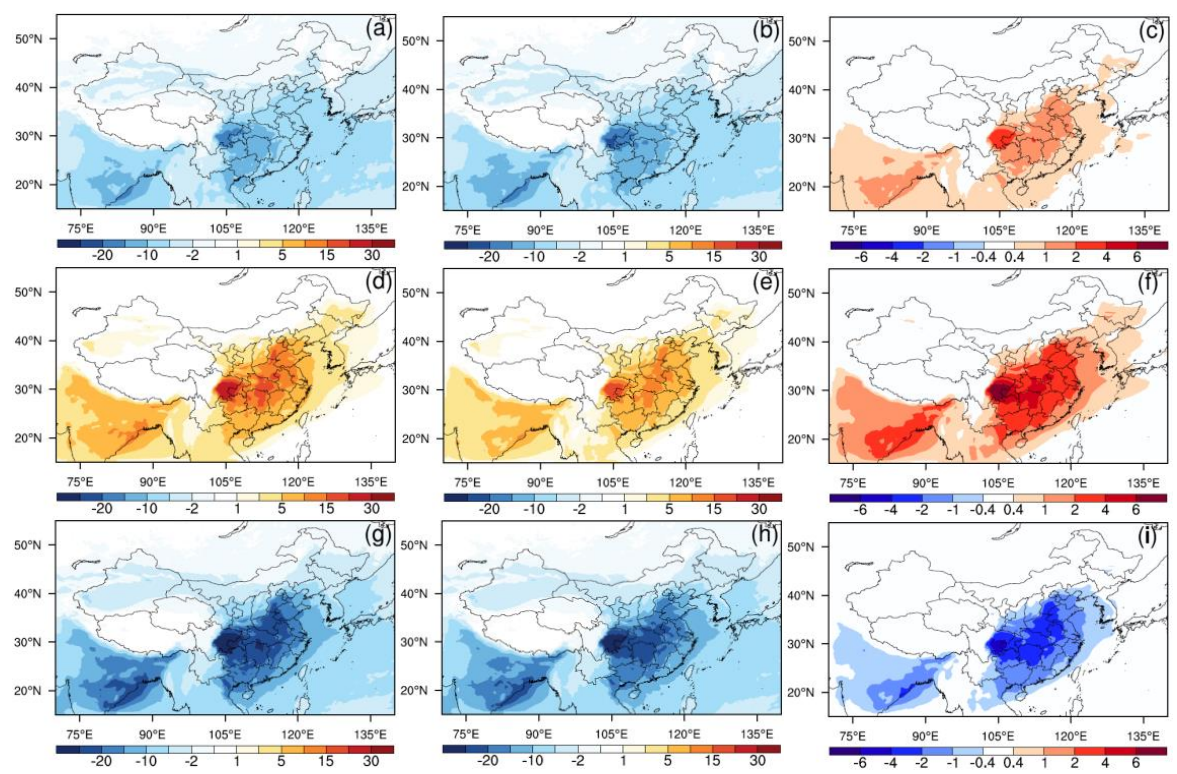

Fig.9. DRF under all sky, TOA, ATM, and SRF from top to bottom. The DRFs shown from left to right are the results from COAT (a,d,g), NoCoat (b,e,h), and their differences $(\mathrm{c}, \mathrm{f}, \mathrm{i})$. 
$\mathrm{M}_{\mathrm{R}}$
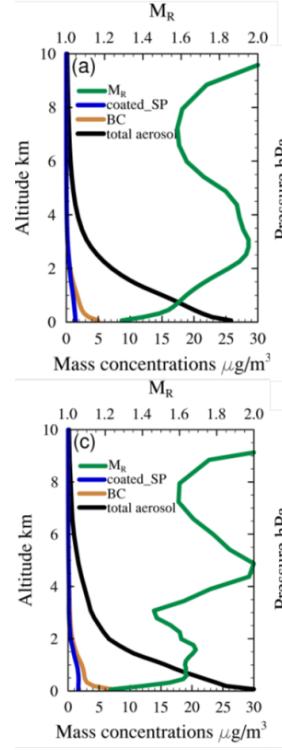
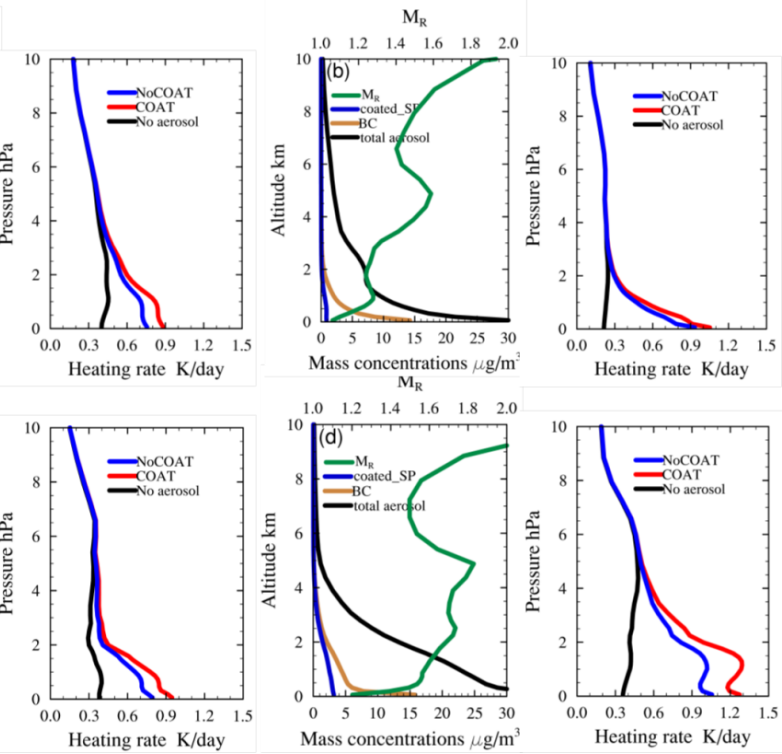

Fig.10. Mass concentrations of total aerosol, $\mathrm{BC}$ core, coated-SP, and $\mathrm{M}_{\mathrm{R}}$ are shown in the left, while heating rate from the experiments COAT, NoCOAT, and no aerosol in the right, over ECC (a), Beijing (b), Nanjing (c), and Chengdu (d). 
Table 1. The monthly mean BC core mass, coated SS mass, the ratio of total mass (BC core + coated SS) to the BC core mass $\left(\mathrm{M}_{\mathrm{R}}\right)$, optical depth (AOD), absorption AOD (AAOD), direct radiative forcing at TOA and surface under clear sky and all sky over East Asia (EA) and East-Central China (ECC) from the experiment COAT and NoCOAT (in brackets).

\begin{tabular}{|c|c|c|c|c|}
\hline & \multicolumn{2}{|c|}{ EA } & \multicolumn{2}{|c|}{ ECC } \\
\hline $\mathrm{BC}$ core mass $\left(\mathrm{mg} \mathrm{m}^{-2}\right)$ & 1.07 & $(1.07)$ & 5.00 & $(5.00)$ \\
\hline Coated SS mass $\left(\mathrm{mg} \mathrm{m}^{-2}\right)$ & 0.39 & (NA) & 1.45 & (NA) \\
\hline $\mathrm{M}_{\mathrm{R}}$ & 1.36 & (NA) & 1.29 & (NA) \\
\hline AOD & 0.36 & $(0.37)$ & 0.86 & $(0.88)$ \\
\hline AAOD & 0.009 & $(0.006)$ & 0.037 & $(0.026)$ \\
\hline Clear sky DRF $\mathrm{TOA}_{\mathrm{TOA}}\left(\mathrm{W} \mathrm{m}^{-2}\right)$ & -6.76 & $(-7.18)$ & -13.89 & $(-15.02)$ \\
\hline Clear sky DRF $\mathrm{DRF}_{\mathrm{SR}}\left(\mathrm{W} \mathrm{m}^{-2}\right)$ & -9.35 & $(-9.02)$ & -24.53 & $(-22.66)$ \\
\hline All sky $\operatorname{DRF}_{\mathrm{TOA}}\left(\mathrm{W} \mathrm{m}^{-2}\right)$ & -3.98 & $(-4.32)$ & -8.34 & $(-9.35)$ \\
\hline All sky $\quad \operatorname{DRF}_{\text {ATM }}\left(\mathrm{W} \mathrm{m}^{-2}\right)$ & 2.43 & $(1.76)$ & 9.49 & $(6.84)$ \\
\hline All sky $\quad \mathrm{DRF}_{\mathrm{SRF}}\left(\mathrm{W} \mathrm{m}^{-2}\right)$ & -6.41 & $(-6.08)$ & -17.83 & $(-16.19)$ \\
\hline
\end{tabular}

Table 2. The statistics (mean and standard deviation) of the modeled AAOD from two experiments (COAT and NoCOAT).

\begin{tabular}{lcclll}
\hline & \multicolumn{2}{l}{ COAT } & & \multicolumn{2}{l}{ NoCOAT } \\
\cline { 2 - 3 } \cline { 5 - 6 } & mean & std & & mean & std \\
\hline Beijing & 0.046 & 0.044 & & 0.036 & 0.030 \\
Hong-Kong-PolyU & 0.015 & 0.011 & & 0.011 & 0.007 \\
Xianghe & 0.050 & 0.037 & & 0.038 & 0.024 \\
Kanpur & 0.021 & 0.007 & & 0.016 & 0.005 \\
Chen-Kung-Univ & 0.008 & 0.004 & & 0.006 & 0.003 \\
\hline
\end{tabular}

